\title{
Reforms for culmination of the deadlock in appellate body of WTO: An agenda of saving the multilateral trading system
}

\author{
Asif Khan* $\mid$ Ximei Wu \\ School of Law, Zhengzhou University, Henan, China. \\ *Correspondence Email: drasifphdlaw@yahoo.com
}

Published: August 18, 2021

\begin{abstract}
The World Trade Organization's (WTO's) dispute settlement mechanism, known as the "pearl in the crown," is stalled due to United States (U.S.) obstruction, which prevents appellate body members from being ordained. This situation continues, and the WTO's dispute settlement function is paralyzed since 2019. The WTO has faced a crisis in recent years, and the trade legislation has stagnated. The dispute settlement body was also blocked due to U.S. interference, which led to the failure of the appellate body's members to be selected. The data has been gathered for this descriptive study using secondary research method, including different newspaper articles and the internet, which were outlined and noted. This paper presents and evaluates several existing proposals on how to get out of the impasse. This paper points out whether the existing WTO members can choose to join or not participate in establishing a new appellate body. On this basis, it makes its own relatively unique proposal, namely, to establish a substantial dispute settlement mechanism outside the WTO, parallel to the existing dispute settlement mechanism, and it demonstrates the legal feasibility of the proposal. Immediately, the states should begin negotiations on the significant agreements required for this new appellate body. It will effectively solve the deadlock in the dispute settlement mechanism caused by the United States, blocking the appointment of members of the appellate body.
\end{abstract}

Keywords: World Trade Organization (WTO), Dispute Settlement Understanding (DSU), appellate body, deadlock, proposal, reforming, multilateral trading system.

\section{How to Cite:}

Khan, A., \& Wu, X. (2021). Reforms for culmination of the deadlock in appellate body of WTO: An agenda of saving the multilateral trading system. Journal of Humanities, Social and Management Sciences (JHSMS), 2(1), 50-62. https://doi.org/10.47264/idea.jhsms/2.1.5

Publisher's Note: IDEA PUBLISHERS (IDEA Journals Group) stands neutral regarding jurisdictional claims in the published maps and institutional affiliations.

Copyright: (C) 2021 The Author(s), published by IDEA PUBLISHERS (IDEA Journals Group) This is an Open Access article published under the Creative Commons Attribution-Non Commercial 4.0 International License (http://creativecommons.org/licenses/by-nc/4.0/) 


\section{Introduction}

World Trade Organization dispute settlement machine is governed by understanding dispute settlement rules and procedures (Rules, 1994). The WTO has formed a Dispute Settlement Body (DSB) to resolve trade disputes among its members, according to Dispute Settlement Understanding (DSU). The DSB shall create an expert group or appeal body within a specified period and report to the expert group and appeal body (Rules, 1994, art. 02). Like the domestic court system that ensures domestic law enforcement, the WTO dispute settlement mechanism ensures the practical international application of international trade rules by resolving disputes among its members. The dispute settlement mechanism of WTO has been regarded as the "pearl on the crown" since its establishment in 1995 (WTO disputes reach 400-mark 2009). Around June 2018, the WTO registered more than 500 complaints and made more than 350 judgments (Kong \& Guo, 2019).

Nevertheless, the WTO has faced a crisis in recent years, and trade legislation has stagnated. Among them, the dispute settlement body was also blocked due to U.S. interference, which led to the failure of the appellate body's members to be selected. America's desire for cooperation is attributable to the "America First" strategy of the current Trump administration (The Doha Round, 2001). Therefore, to find a solution to the problem, this paper suggests forming a new appeal body with the current appeal body for dispute resolution.

The first part of this paper introduces the myth of "us first" and the related U.S. trade policy. The second part describes the current impasse in the multilateral trading system. The third part discusses several solutions to existing problems and evaluates them accordingly. The fourth part puts forward the main point of this paper: to establish a new appellate body and examine the proposal's legal feasibility. The fifth part summarizes policy recommendations.

\subsection{Methodology}

Looking at the parameters for the purposes of this study, the research involved or planned for research focuses on a variety of resources. In order to have greater accuracy and richness analyses of the study research, this research design was adopted in light of the set objectives. Accessible secondary data has been used for extensively. The data has been gathered using secondary research method, including different newspaper articles and the internet, which were outlined and noted. Various journals, books, reviews, articles, treaty obligations, public documents, norms, legal maxims, and precedents were also taken into consideration and recorded where necessary. Furthermore, the research strategy is based on qualitative methods. These research methodologies has been used because it is a library-based study concerning multiple publications, articles, international journals, reviews, and published papers. The primary sources of data collection are internet sites and worldwide books from web pages.

\section{Deadlock in the multilateral trading system}

\subsection{Intensified and differentiated trading system}

The United States and its allies successfully established the WTO more than 20 years ago to support free global trade. Its rules govern all aspects of global trade, including the exchange of goods, the exchange of services, and the exchange of intellectual property rights. However, the 
Reforms for culmination of the deadlock in appellate body of WTO: An agenda of saving ...

current system has been gradually ageing, and no substantial progress has been made in the new round of Doha Round negotiations (Board, 2016). No substantial progress has been made. Due to the difficulty in reaching a unanimity among developed and developing states, the failure to reach an effective agreement during the 2015 Nairobi conference was once regarded as a failure of the Doha round (CPTPP, 2017). In response to the inefficient WTO multilateral trade negotiations, the U.S. former president Obama administration decided to strengthen trade rules through regional agreements such as the Trans-Pacific Partnership Agreement (TPP) and the transatlantic trade and investment partnership agreement (TTIP). Although the U.S. Trump administration has withdrawn from the TPP, other countries have changed its name slightly and signed the comprehensive and progressive Trans-Pacific Partnership Agreement (Gillespie, 2018).

The original high standard trade agreement's content is still retained, which reflects the dissatisfaction of various countries to the current multilateral trading system (Hong \& Park, 2020). The Trump administration's push to renegotiate the North American Free Trade Agreement (NAFTA) and repeatedly threatened to withdraw from the WTO has added uncertainty to the already fragile global trade system. Trump had complained about the WTO dispute settlement mechanism, claiming that the U.S. has lost "virtually all WTO litigation" and that the reason for this is that he believes the U.S. has fewer judges than other countries, resulting in the U.S. not being in the majority when the panel was established (Kong \& Guo, 2019). This view is groundless. According to the empirical analysis of all WTO disputes by scholars, the U.S.won $91 \%$ of the cases as the complainants and lost as the respondent in $89 \%$ of the cases; however, the complainants won in $90 \%$ on average of the cases (Koh, 2019). In other words, the respondent loses $90 \%$ of the cases. This is because petitioners' governments do not generate WTO disputes unless they are very confident they can win (Gantz, 2018). These data show that the United States is not in a disadvantageous position in the WTO dispute settlement mechanism; by contrast, the United States' success rates in appealing and responding to lawsuits are $1 \%$ higher than the average level. Additionally, the US criticized the appeals process and representatives of the appellate body (DSU, art. 17(5)). According to DSU, the appellate body cannot adjudicate for more than 90 days. The United States points out that the appellate body frequently delays judgements. The US also raised concerns about members of the appellate body continuing to hear cases after their term has ended.

Moreover, the U.S. considers that the appellate body's individual decisions have exceeded its competence and are establishing new rules (Farewell speech, 2018). Accordingly, the U.S. has prohibited members of appellate body from being selected and reappointed. For instance, the U.S. has opposed the re-election of (Chang Seung-Hwa), a member of the Korean Nationality appeals board. It should be noted that the objection was raised by the Obama Administration, not by the Trump Government. Research shows the consistency of the two successive U.S. administrations' policies intimidating the WTO dispute settlement mechanism. The Trump administration also continued to oppose the selection of the Appeals Board members by the Dispute Settlement Body in August 2017, paralyzing the entire appeals system (Statement by the U.S., 2016).

Mr Peter Van den Bossche (Billy), Mr Ricardo Ramírez-Hernández (Mexico) and Mr Hyun Chong Kim (Korea) concluded their term of office in 2017. Mr Shree Baboo Chekitan Servansing (Mauritius) has also just completed his first term of office on September 30, 2018. As a result, only three of the seven posts in the WTO appellate body were in office as of October 
1, 2018, barely enough to meet the minimum number of members of the appellate body who can function correctly (Statement by the US, 2016). At present, the appellate body is not able to review appeals because the members of last body expired on 30 November 2020.

Although the U.S. has been criticizing the WTO dispute settlement body and has continuously prevented the members of the appeal body's appointment, the U.S. has still resorted to the WTO dispute settlement mechanism for trade disputes. Since Trump took office, the United States has targeted Canada and India, respectively, China and China have filed several cases with the WTO (DSU, art. 17(1)).

\subsection{Vulnerability and weakness of dispute settlement mechanisms}

The current impasse facing the dispute settlement mechanism stems from the consensus mechanism in the DSU, which means that all decisions are subject to the unanimous consent of the members. The dispute settlement body shall nominate members of the appellate body for four years, each of whom may be appointed once. However, the decision of the DSU to require litigation should be made by consensus (DSU, art. 17(2)). Under the WTO Arrangement, the WTO continues to take consensus decisions under GATT procedures (DSU, art. 2(4)). Merit Janow and Jennifer Hillman were among the United States appellate body members who were successfully blocked from being appointed by the United States based on this consensus mechanism. In several rulings against the United States, they have expressed disagreement with the official U.S. position (WTO agreement, art. 9(1)). In the absence of clear evidence, it is hard to say whether the United States blocked their appointment. By obstructing the selection of appellate body members with a single objection, any WTO member can achieve the political goal of manipulating the appellate body (Dunoff \& Pollack, 2017).

Some scholars have regarded this consensus mechanism as a "design flaw" of the system (Shaffer et al., 2016). The proponents of the WTO Agreement could not have expected that members would misuse this procedure. During the GATT period, such a consensus mechanism has been formed in the multilateral trading system, including the need for the respondent's consent when the expert group is established (Bacchus, 2018). However, the respondent usually does not use the consensus mechanism to hinder the settlement of disputes. This is because allowing dispute resolution can harm short-term interests, but it also benefits long-term litigants. They know that excessive use of the veto will lead to similar actions by other members, which will further damage one member's interests in international trade (World Trade Organization, 2017).

\section{Solutions to save the multilateral trading system}

To break the current impasse, this section presents three potential scenarios for improving the multilateral trading mechanism, including (a) waiting for the return of trade liberals in the United States; (b) Revitalizing trade regionalism; (c) Rely on the existing WTO rules. Each proposal is further evaluated in this section.

\subsection{Waiting for the return of American trade liberals}

The first is to wait for the return of American trade liberals. Trade liberals support international trade, and their return is expected to promote the operation of international trade. However, it 
Reforms for culmination of the deadlock in appellate body of WTO: An agenda of saving ...

should be noted that this expectation is uncertain and cannot solve the severe problems that the appellate body has already faced in the short term. Trump's first term will expire at the end of 2020. Even if a liberal president takes over, by then, the appellate body may have ceased to function because no new members have been appointed.

Moreover, trade liberals cannot guarantee that they will win the next U.S. election. Trade protectionism has a place among American citizens. For example, Robert Lighthizer, the U.S. trade representative, has been opposed to the WTO since its establishment, especially the WTO dispute settlement mechanism. In the absence of evidence, he even openly suspected that WTO referees were corrupt (World Trade Organization, 2017). Besides, he cites many conservatives in American history, including Alexander Hamilton and Ronald Reagan, and emphasizes that liberalism has no practical significance (Kong \& Guo, 2019). This suggests that relying solely on trade liberals' return may be too opportunistic and does not guarantee an effective solution to the WTO's predicament.

Moreover, it should not be ignored that U.S. trade liberals do not necessarily support the multilateral trading system. The prime example is the Obama administration's trade policy. As mentioned earlier, the Obama administration is supposed to be a champion of free trade. However, it is actively involved in TPP and TTIP negotiation, aiming to create a set of trade rules beyond the WTO (Lighthizer, 2008). Also, concerning dispute resolution, particularly the appellate body, the Obama administration has blocked the re-appointment of a member of the appellate body by questioning its independence and impartiality (Hamilton, 2014). So relying solely on American trade libertarians' return will not necessarily solve today's multilateral trade problems facing the system.

\subsection{Revitalizing trade regionalism}

Second, revitalizing trade regionalism, and multilateral trade has been dominant from GATT to WTO since World War II. However, Trade regionalism cannot be overlooked, such as Europe, North America, South America and other trade bloc-forming areas (Kuijper, 2017). In recent years, trade regionalism, driven by complex economic and political motives, has made a comeback. That is partly because of the slow pace of negotiations under the WTO's multilateral system (Bartels et al., 2015). Trade regionalism could be an alternative to the current impasse at the multilateral level. Many regional preferential trade agreements (PTAs) have established dispute settlement clauses like the WTO dispute settlement mechanism in terms of dispute settlement. In practice, the regional dispute settlement process, on the other hand, is rarely used. It is possible that many of the parties to regional agreements are WTO members and prefer WTO dispute resolution mechanisms. Because of its multilateralism, the WTO's dispute settlement mechanism is able to ensure that all parties have a reasonable understanding of legal texts. Aside from that, the WTO's dispute settlement mechanism has ruled on hundreds of cases and has slowly built up a good reputation in the industry. Because of this, it's difficult for the regional dispute resolution system to deal with it in a timely manner While trade regionalism may be an alternative to multilateralism in some respects, it is never a complete substitute.

\subsection{Review of WTO rules}

The third solution is to use the existing WTO rules and find a solution to the WTO's deadlock 
based on the existing text. Based on this method, scholars also put forward various hypotheses. Steve Charnovitz suggested changing article 20 of the appellate body's working procedure.. He recommended that a new clause be drafted in the event that the terms of office of three or more members of the appellate body expire, and that the new appeal be completed automatically on the day of the appeal (Kong \& Guo, 2019). In other words, the expert report will be the final decision and adopted by the dispute settlement body. Such a proposal abandons the appellate body mechanism, which cannot effectively solve the appellate body's difficulties but will cause more concerns of WTO members about the appeal mechanism.

Scott Anderson and others proposed that the article 25 arbitration clause of DSU can be used as an alternative to the appeal mechanism (Charnovitz, 2019). Under the article, the existing WTO framework allows arbitration as an alternative to dispute settlement (Andersen et al., 2017). Under this scheme, following the release of the panel report, the parties may with their consent appeal to the WTO arbitration authority; the list of arbitrators may include former members or current members of the appeal body (DSU, art. 25 (1)). However, several questions remain as to whether this arbitral approach is an alternative to the appellate body. Firstly, only the legal issues in the expert report and the legal interpretations made by the jury can be heard by the appellate body. In the contrary, the autonomy of the will is the foundation of the arbitration. Both parties can decide the content of the award by agreement (Andersen et al., 2017). Moreover, the parties can also agree to award all facets of the disputed issue during the arbitration proceedings, with utter disregard for the panel report's results. This would make the panel ineffective. Second, arbitration is temporary, selecting arbitrators from the arbitrator panel. The members of the expert group are also selected from the list of WTO experts. In this sense, the arbitration procedure is closer to the panel procedure (DSU, art. 25(2)). The secretariat generally proposes the members of the expert group, and in exceptional cases, the director-general may directly appoint the members of the expert group. Besides, the appellate body's seven members are permanent. Such a permanent structure will have greater judicial stability and procedural certainty for future prosecutions. On the contrary, the interim arbitration process cannot guarantee the permanent appellate body's consistency and certainty.

Pieter Jan Kuijper suggested invoking the majority clause. The WTO Agreement provides unless otherwise provided, that when the majority cannot make a judgment, the matter in a conflict shall be resolved by vote (Kuijper, 2017). The WTO framework also extends to the dispute resolution mechanism. Thus, this voting mechanism can also be used to appoint appealing body members. It would be remarked that the majority mechanism referred to here only applicable to extraordinary situations. Kuiper further added that current members of the WTO are likely to strongly oppose the majority. He proposed another solution: a new "court of appeal" could be formed outside of the WTO, and ex-members of the appeal body could resign themselves to join the new judiciary. The new court may also adjudicate disputes regarding regional trade agreements. A new international trade tribunal will be set up but without the rules of the WTO (WTO Agreement, art. 16).

\section{New proposal: Establishing a new appeal mechanism with a substantial agreement}

\subsection{Proposal design}

Under the framework of WTO, the dispute settlement mechanism provides the practice of legal certainty and judicial credibility for the settlement of global trade disputes. At present, there is 
Reforms for culmination of the deadlock in appellate body of WTO: An agenda of saving ...

no other alternative form that can play the same role as the WTO dispute settlement body. This paper's starting point is to retain the current dispute settlement mechanism to the greatest extent and find a solution to the current dilemma. Therefore, this paper proposes to establish a new open appeal body.

The proposal is divided into two sections. Part one's goal is to keep the current dispute resolution system in place, including the expert group and the appeals process. At present, all WTO members are participants in the dispute settlement mechanism. The WTO Agreement and the DSU still govern the composition and order of work of the existing expert group and the appellate body. Despite the U.S. obstruction, the first three members of the Appeals Body could function in theory in December 2019. The second part is to resolve the current impasse. As mentioned earlier, the DSB will soon be unable to function normally under the U.S. continued non-cooperative attitude. Therefore, this paper proposes to establish a new open appeal body. In this framework, the panel procedure is not affected. However, compared with the original appellate body, the new appellate body does not need all members' full participation. WTO members who accept the proposal can automatically choose to join.

On the other hand, non-accepting members may choose not to participate. Participants in the new appellate body will jointly elect seven new members. This means that any disputes between the parties to the new appellate body agreement can only be resolved by the new appellate body. One or more of the new appellate body's non-participating members are involved in a dispute. The original appellate body may only hear it. When the original appellate body cannot function, the existing WTO members either give up the WTO's dispute settlement or join the new dispute settlement mechanism.

\subsection{Legal feasibility assessment}

\subsubsection{Legal options for the new appellate body}

The establishment of such an appellate body needs to be based on a solid legal foundation. Therefore, it is necessary to find the most suitable option in law. The first option is to modify the text of the DSU by adding provisions that allow some members to set up new appellate bodies among themselves under specific circumstances. The author thinks that the DSU is an agreement applicable to all WTO members currently, and it is unrealistic to set up a new appellate body by modifying the DSU. One of the reasons is that the amendment of the DSU involves the institutional interests of the U.S. in the WTO; the other is that both WTO Agreement and DSU have provided for a consensus mechanism, (WTO Agreement, art. 16). The establishment of the new appellate body within the framework of the DSU needs to modify the current DSU or renegotiate the new DSU, which may encounter substantial obstruction from the U.S.

A second possible option for a new appellate body would be a new plurilateral agreement within the WTO framework. There are several plurilateral trade agreements under the WTO, such as the Civil Aircraft Trade Agreement and the Government Procurement Agreement (WTO agreement, art. 9(1); DSU, art. 2(4)). The legal basis for these plurilateral trade agreements is article 2 of the WTO Agreement. Article 03 provides that the plurilateral trade agreements included in Annex 4 apply only to and are binding on those Members who have accepted them (Arrowsmith, 2002). This option includes the new dispute settlement agreement 
into the new multilateral agreement of WTO, that is, to add the new agreement to Annex 04 of WTO. In this regard, the author still believes that this option is not realistic. The reason is: under this option, WTO ministerial conference Under the provisions of the WTO agreement, the conference must decide by consensus to include it in the new multilateral agreement of the WTO. In other words, even adding a Plurilateral agreement still requires consensus, including the consent of the United States. Although the establishment of the new appellate body will not involve the trade disputes to which the United States is a party and will not have a significant impact on the United States. The United States has no moral legitimacy and strongly opposes this proposal, considering that the intention of US to paralyze the appellate body is to force other members to accept the request put forward by the United States (WTO Agreement, art. 10(9)) the United States opposes the inclusion of the new agreement into the WTO The possibility of plurilateral agreements cannot be ruled out. This option is not appropriate.

The third option of the new appellate body is a bolder option, that is, to bypass the existing framework and conclude a large-scale agreement aimed at establishing a new appellate body, rather than adding the new agreement to Annex 04 of the WTO agreement, to avoid the possible uncertainty caused by the consensus mechanism. In other words, WTO members who intend to create a new appellate body will redraft a new Appellate Body agreement. Since the agreement is not a multilateral agreement within the WTO framework, it can only be reached through negotiations among the participating members without considering the opinions of non-participating members.

\subsubsection{The legal feasibility of concluding agreements outside the WTO framework to create a new appellate body}

Is the third option of the new appellate body's legal text, namely, to conclude such an agreement outside the WTO framework to establish a new appellate body, legally feasible under international law? Or, on the other hand, is there an obstacle under international law? The author believes that article 41 of the Vienna Convention on the law of treaties specifically sets rules for amending multilateral treaties only among several parties. In other words, it provides a basis for some parties to a multilateral treaty to conclude follow-up agreements on matters regulated by the multilateral treaties, to apply the new agreements among them. "Article 41 agreement to amend a multilateral treaty only among several parties. Two or more States parties to a multilateral treaty may agree only to amend the treaty between them in the following circumstances:

- The possibility of such modification is provided for in the treaty;

- Or the amendment is not prohibited by the treaty,

- Furthermore, it does not affect the other parties' rights or obligations under the treaty.

- Does not concern any provision which, if restrained, is incompatible with the object and purpose of the treaty" (Vienna Convention, art. 41).

It is generally believed that if some states parties to a multilateral treaty want to amend the multilateral treaty through subsequent agreements, the conditions stipulated in article 41 must be met simultaneously. The following is a discussion on whether some of its members are prohibited from concluding such an agreement under the specific provisions of article 41 of the Vienna Convention on the law of treaties. Although the WTO agreement does not explicitly stipulate whether some of its members have the right to agree applicable only between them, it 
Reforms for culmination of the deadlock in appellate body of WTO: An agenda of saving ...

is not difficult to see that it does not prohibit some of its members from entering into such an agreement. Make such an agreement. What is more, whether the existence of the Plurilateral agreement, which was concluded before the establishment of the WTO on January 1, 1995, or the trade facilitation agreement concluded in 2013, which allows members to choose to join Vienna Convention article 41 indicates that the WTO agreement does not prohibit some of its members from concluding subsequent agreements that are applicable only between them.

Then, whether the scheme meets the requirements of "not affecting the rights or obligations of other parties to the treaty". In this proposal, the new agreement to create a new appellate body does not affect the rights and obligations of other WTO members who do not intend to participate in the new agreement to use the original appellate body under the WTO agreement. So, the next question is: is the agreement aimed at creating a new Appellate Body inconsistent with the WTO Agreement and the purposes and purposes of the DSU?

The author finds that the WTO framework, including DSU, is intended to establish a unified dispute settlement body among all WTO members. However, it does not exclude the existence of such a dispute settlement mechanism among some WTO members. Some WTO members have concluded many regional trade agreements. Some regional trade agreements have their unique dispute settlement mechanism (such as the Usmca agreement concluded by the United States, Canada, and Mexico, which was reformed from the original NAFTA) and have its dispute settlement mechanism. It can be seen from this point that conclusion of an agreement between some WTO members aimed at creating a new appellate body cannot be regarded as inconsistent with the objectives and purposes of the WTO agreement (and the DSU).

Moreover, at present, the WTO Appellate Body is in crisis, so the conclusion of such an agreement is also to save the appeal mechanism and the WTO based on rules. In essence, it is conducive to realizing the purpose and purpose of the WTO Agreement (and DSU). Therefore, it cannot be said that the scheme proposed in this paper is incompatible with the conditions stipulated in article 41 of the Vienna Convention on the law of treaties. To sum up, there is no obstacle under article 41 of the Vienna Convention on the law of treaties, which constitutes customary international law, to conclude agreements aimed at establishing a new appellate body outside the WTO framework.

\subsection{The relationship between the original appellate body and the new appellate body}

The establishment of the new appellate body has not led to the abolition or suspension of the original appellate body's application. There is a problem here: if the United States changes its position that hinders the appellate body and the original Appellate Body revives, how should the relationship between the new appellant and the original appellant be handled? The author believes that there is a position that hinders the appellate body in theory because of the change of the United States. Although the possibility of the original appellate body reviving is very slight, it needs to be considered. The author believes that the new appellate body has completed its mission. The purpose of establishing the new appellate body is not to compete with the original appellate body, but to continue to retain the appeal mechanism when the appellate body is facing deadlock or paralysis to play a role. Once the original appellate body's function is restored, the newly established appellate body will not accept new cases. It will cease to play its role after the settlement of existing disputes. This provision can be set up in advance in the agreement to establish a new appellate body through negotiation. 
However, from the realistic possibility, if the new appellate body is established and most WTO members are willing to join the new appellate body, the original appellate body may only deal with cases involving a few members. Although some members, such as the United States, were the most active participants in the WTO dispute settlement body in the past, the original appellate body's cases will be less and less. In this sense, after establishing the new appellate body, the original appellate body may gradually lose its significance in the WTO system. Other members are more motivated to participate in the new appellate body.

\subsection{Problems to be solved in establishing a new appellate body outside the WTO Framework}

The above analysis illustrates the legal basis of this new appellate body. However, in the specific implementation process, there may be some operational problems. The response to several possible questions is: Firstly, the selection and appointment of the current body of appeal members. The appointment of new members does not require non-participating members, such as the United States. Since the original appellate body and the new appellate body are parallel systems, it is not recommended to allow the same person to serve both the original and the new appellate bodies. Effective isolation will ensure the fairness of the dispute settlement mechanism. It should be pointed out that under the circumstances that the U.S. cannot change its position and stop the appointment of members of the appellate body, it can be determined that the current appellate body will not exist in fact by the end of 2019 . Therefore, it will not be possible for the two appellate bodies to exist at the same time. The second issue is that the new appellate body's cost may also require further clarification and whether the new appellate body has access to the WTO Secretariat resources. It should be said that non-participating members are not liable for the expenses of the new appellate body. One possible approach would be to provide for the apportionment of the new appellate body's expenses in the drafting of the agreement aimed at establishing it. The third issue concerns the legal effect of the original and new Appellate Body reports. It should be said that these reports can be used as guidance for subsequent cases. Although WTO has a de facto case law system, WTO itself is a case law system

Therefore, previous reports should only be used as the source of interpretation of WTO rules. In this way, the old report can be used as cited in the new report. Members of the new appellate body may refer to previous rulings based on this. However, they must restrain their own opinions on WTO rules, Expand the interpretation, and keep a consistent and unified interpretation path.

\section{Conclusion}

This paper points out that the existing WTO members can choose to join or not participate in establishing a new appellate body. This new mechanism is similar to the original dispute settlement mechanism in most respects; the only difference is that the new mechanism does not need to apply to all members. The advantage of the proposal lies in that it retains WTO's role and function as a multilateral trading system to a large extent. However, it effectively solves the deadlock in the dispute settlement mechanism caused by the United States, blocking the appointment of members of the appellate body. Since the existing WTO members' rights are not substantially affected, the proposal is expected to encounter a minimum of political opposition. However, it is most important to point out that this deadlock needs to be resolved 
Reforms for culmination of the deadlock in appellate body of WTO: An agenda of saving ...

in the shortest possible time, and the new agreement should be negotiated and completed within a short period. As mentioned earlier, the existing appellate body is not able to operate normally from December 2019. In any case, members should start to deal with it as soon as possible and start negotiations specifically to establish a new appellate body.

\section{References}

Andersen, S., Friedbacher, T., Lau, C., Lockhart, N., Remy, J. Y., \& Sandford, I. (2017). Using arbitration under article 25 of the DSU to ensure the availability of appeals (No. Book). The Graduate Institute of International and Development Studies, Centre for Trade and Economic Integration.

Arrowsmith, S. (2002). Reviewing the GPA: The role and development of the Plurilateral agreement after Doha. Journal of International Economic Law, 5(4), 761-790. https://doi.org/10.1093/jiel/5.4.761

Bacchus, J. (2018). Might unmakes right: The American assault on the rule of law in world trade. Centre for International Governance Innovation (CIGI) Paper No. 173. https://www.cigionline.org/publications/might-unmakes-right-american-assaultrule-law-world-trade/

Bartels, L., Lester, S., \& Mercurio, B. (Eds.). (2015). Bilateral and regional trade agreements: Commentary and analysis. Cambridge University.

Board, T. E. (2016, January 1). Global trade after the failure of the Doha Round. The New York Times. https://www.nytimes.com/2016/01/01/opinion/global-trade-after-the-failureof-the-doha-round.html.

Charnovitz, S. (2019). How WTO dispute settlement succumbed to the Trump administration. GWU Law School Public Law Research Paper No. 2019-73. https://dx.doi.org/10.2139/ssrn.3505266

CPTPP. (2017). 11 Asia-Pacific countries that initiated the TPP negotiations jointly issued a joint statement announcing that "a fundamental and important consensus has been reached on the new agreement" and decided to change its name to "Trans-Pacific Partnership". Progress Agreement (CPTPP). http://www.glory-fiber.com/NewsInfo970.html

DSU. (article 17(1)). This article stipulates that the appeal body shall consist of seven persons, and three persons shall be appointed in any case. ([The AB] shall be composed of seven persons, three of whom shall serve on any one case). https://www.wto.org/english/tratop_e/dispu_e/dsu_e.htm

DSU. (article 17(2)). https://www.wto.org/english/tratop_e/dispu_e/dsu_e.htm

DSU. (article 17(5)). According to this provision, under normal circumstances, no more than 60 days from the submission of the appeal application to the issuance of the appeal body's decision, and in special cases it can be extended to 90 days. (As a general rule, the proceedings shall not exceed 60 days from the date a party to the dispute formally notifies its decision to appeal to the date the appellate body circulates its report. In no case shall the proceedings exceed 90 days). https://www.wto.org/english/docs_e/legal_e/28-dsu_e.htm

DSU. (article 2(4)). https://www.wto.org/english/tratop_e/dispu_e/dsu_e.htm

DSU. (article 25(1)). Expeditious arbitration within the WTO as an alternative means of dispute settlement can facilitate the solution of certain disputes that concern issues that are clearly defined by both parties. 
Dunoff, J. L., \& Pollack, M. A. (2017). The judicial trilemma. American Journal of International Law, 111(2),

225-276. https://www.cambridge.org/core/journals/american-journal-of-internationallaw/article/abs/judicial-trilemma/3D8A825187AC1C34410B6C5281607E40

Farewell Speech (2018). Farewell speech of appellate body member Ricardo RamírezHernández.

WTO. https://www.wto.org/english/tratope/dispue/ricardoramirezfarwellspeeche.htm.

From January 1, 1995 to December 20, 2018, the United States filed 123 complaints, responded to 151 cases, and participated in 147 cases as third parties. https://www.wto.org/english/tratope/dispue/dispubycountrye.htm

Gantz, D. A. (2018). An existential threat to WTO dispute settlement: blocking appointment of Appellate Body members by the United States. Arizona Legal Studies Discussion Paper No.18-26. https://dx.doi.org/10.2139/ssrn.3216633

Gillespie, T. P. (2018). 11 countries sign TPP trade pact without the United States. CNN Money. https://money.cnn.com/2018/03/08/news/economy/tpp-trump-tariffs/index.html.

Hamilton, D. S. (2014). America's mega-regional trade diplomacy: Comparing TPP and TTIP. The International Spectator, 49(1), 81-97. https://doi.org/10.1080/03932729.2014.877223

Hong, P., \& Park, Y. W. (2020). The United States-Mexico-Canada Agreement (USMCA) and Japanese Firms. In Rising Asia and American Hegemony (pp. 153-163). Springer. https://link.springer.com/chapter/10.1007/978-981-13-7635-1_10

Koh, H. H. (2019). Trump change: Unilateralism and the "Disruption Myth" in International Trade. Yale Journal of International Law, 44, 96-103. https://cpb-use1.wpmucdn.com/campuspresstest.yale.edu/dist/8/1581/files/2019/02/11_Koh_YJILSymposium_Epilogue_Trump-Change_02.05.19-2kfkph2.pdf

Kong, Q., \& Guo, S. (2019). Towards a Mega-Plurilateral dispute settlement mechanism for the WTO? Journal of World Trade, 53(2). 273-292. https://kluwerlawonline.com/journalarticle/Journal+of+World+Trade/53.2/TRAD20 $\underline{19013}$

Kong, Q., \& Guo, S. (2019). WTO Reform: Will there be a third option other than a US Withdrawal and a China Expulsion. Asian J. WTO \& Int'1 Health L \& Pol'y, 14, 359. https://heinonline.org/HOL/LandingPage?handle=hein.journals/aihlp14\&div=16\&id =\&page $=$

Kuijper, P. J. (2017). The US attack on the WTO appellate body. Legal Issues of Economic Integration, 45(1), 1-15. https://ssrn.com/abstract=3076399

Lighthizer, R. E. (2008, March 6). Grand old protectionists. The New York Times. https://www.nytimes.com/2008/03/06/opinion/06lighthizer.html.

Rules, D. S. (1994). Understanding on rules and procedures governing the settlement of disputes. Marrakesh agreement establishing the World Trade Organization, Annex, 2, 1869.

Shaffer, G., Elsig, M., \& Puig, S. (2016). The extensive (but fragile) authority of the WTO

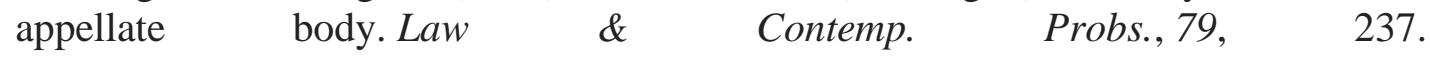
https://heinonline.org/HOL/LandingPage?handle=hein.journals/lcp79\&div=12\&id= $\underline{\text { \&page }=}$

Statement by the United States at the meeting of the WTO Dispute Settlement Body (DSB), WTO. (2016). content/uploads/sites/290/May23.DSB_.pdf . https://geneva.usmission.gov/wp- 
The Doha Round. (2001).https://www.wto.org/english/tratop_e/dda_e/dda_e.htm

WTO Agreement. (article 16). According to this article, the WTO agreement has priority for other multilateral provisions. (In the event of a conflict between a provision of this agreement and a provision of any of the multilateral trade agreements, the provisions of this agreement shall prevail to the extent of the conflict).

WTO Agreement. (article 9(1)). https://www.wto.org/english/rese/publicationse/ai17e/tripsart9jur.pdf

World Trade Organization. (2017). A handbook on the WTO dispute settlement system. Cambridge University.

WTO disputes reach 400 mark. WTO. (2009). https://www.wto.org/english/news_e/pres09_e/pr578_e.htm

WTO, the working procedures for appellate review, WT/AB/WP/6, (August 16, 2010). However, according to Article 15 of the "Working procedures of the appellate body", if the appellate body authorizes and notifies the Dispute Settlement Body, the outgoing Appellate Body members may still and only be able to hear the cases before their resignation. (A person who ceases to be a member of the appellate body may, with the authorization of the Appellate Body and upon notification to the DSB, complete the disposition of any appeal to which that person was assigned while a member, and that person shall, for that purpose only, be deemed to continue to be a member of the appellate body). https://www.wto.org/english/tratop_e/dispu_e/ab_procedures_e.htm

Vienna Convection. (article 41). Vienna Convention on the law of treaties, some parties to a multilateral treaty may conclude an agreement to amend the multilateral treaty so as to use the new agreement between them, unless the original multilateral treaty prohibits any of its parties from entering into such an agreement. 